Çakmak, Abdullah (2020). “Divan-ı Hümayun Kararlarında Bursa Vakıfları (15531649)". Uludağ Üniversitesi Fen-Edebiyat Fakültesi Sosyal Bilimler Dergisi, C. 21, S. 38, s. 187-221.

DOI: $10.21550 /$ sosbilder.584914

Araştırma Makalesi

\title{
DIVAN-I HÜMAYUN KARARLARINDA BURSA VAKIFLARI (1553-1649)
}

\author{
Abdullah ÇAKMAK*
}

Gönderim Tarihi: Temmuz 2019

Kabul Tarihi: Ağustos 2019

\section{ÖZET}

Vakıflar, sosyal hayatta yerine getirdiği birçok hizmetle Osmanlı medeniyetinin önemli müesseseleri arasında yer almaktadır. Bu yönüyle Osmanlı sosyal ve iktisadi hayatını, vakıflar özelinde inceleyen birçok çalışma bulunmaktadır. Bu çalışmalarda araştırmacıların sıklıkla kullandığı iki belge türü vakfiye ve kadı (şer'iyye) sicilleridir. Bununla birlikte Osmanl vakfflarlyla ilgili önemli bilgileri ihtiva eden Mühimme Defterleri serisinin ise çalışmalarda yeterince incelenmediği görülmektedir. Bu çalışma; Divan-ı Hümayun toplantılarında Bursa vakıflarıyla ilgili alınan kararları konu edinmektedir. Çalışmamızın ana kaynağını ise 1553-1649 yıllarını kapsayan klasik dönem Mühimme Defterleri oluşturmaktadır. Buna göre; konuyla ilgili tespit edilen hükümlerden hareketle; alınan kararlarda hangi vakıfların yer aldı̆̆g, dava başvurusunun nasıl gerçekleştirildiği, dava konularının mahiyeti ve kararların vakıfları nasıl etkilediği gibi konular incelenmiştir.

Anahtar Kelimeler: Osmanl, Bursa, vakıf, Divan-ı Hümayun, mühimme defterleri

\section{Bursa Waqfs in the Imperial Council Registers (1553-1649)}

\section{ABSTRACT}

Waqfs are among the most important institutions of Ottoman civilization with the many services they provide in social life. In this respect, there are many studies examining the social and economic life of the Ottoman Empire in the context of waqfs. The two types of documents commonly used by researchers in these studies are the waqfiyyas and Ottoman court records (şer'iye sicils). However, it is seen that

* (D) Öğr. Gör. Dr., Afyon Kocatepe Üniversitesi İslami İlimler Fakültesi İslam Tarihi ve Sanatları Bölümü, acakmak@aku.edu.tr

Uludağ Üniversitesi Fen-Edebiyat Fakültesi Sosyal Bilimler Dergisi Uludağ University Faculty of Arts and Sciences Journal of Social Sciences

Cilt: 21 Sayı: 38 / Volume: 21 Issue: 38 
Mühimme registers series which contains important information about Ottoman waqfs has not been examined sufficiently. This study deals with the decisions taken about Bursa waqfs in Imperial Council sessions. The main source of our study is the Mühimme registers of the classical period covering 1553-1649 years. According to this; on the basis of the provisions determined on the subject; topics such as which waqfs are included in the decisions taken, how the case application was filed, nature of the cases and how decisions affect waqfs were examined.

Key words: Ottoman, Bursa, waqf, Imperial Council, mühimme registers

\section{Giriş}

İslam medeniyetinin, sosyal yardımlaşma ve dayanışmaya verdiği önemin kurumsal tezahürü vakıf müessesesidir. Vakıflar, İslamiyet'in doğuşundan günümüze değin dinî, sosyal, eğitim, beledî ve iktisadî gibi hayatın birçok alanına temas ederek toplum hayatında önemli bir rol üstlenmişlerdir.

Vakıf müessesesinin teorik kısmına yönelik hukukî boyutu ve tarihsel gelişimi hakkında literatürde birçok çalışma bulunmaktadır ${ }^{1}$. Son yıllarda artış gösteren Osmanlı dönemi sosyal ve iktisadi hayatını vakıflar özelinde inceleyen çalışmalarda ise kaynak olarak daha çok vakfiye ve kadı sicillerinin kullanıldığı görülmektedir. Bir vakfın idaresini, gelir-giderlerini ve personelini tespit etmeye yarayan vakfiyelerin yanı sıra özellikle vakıf anlaşmazlıkların hangi sebeplerle gerçekleştiğini ortaya koyması bakımından kadı sicilleri oldukça zengin bilgileri haizdir (Orbay 2005: 27-41). Ancak bu ikisi dışında vakıflarla ilgili yine son derece önemli bilgileri ihtiva eden ve çoğu araştırmacı tarafindan ihmal edilen arşiv kaynağı ise Divan-1 Hümayun'da görülen davalara ait kayıtlardır.

\footnotetext{
${ }^{1}$ Vakıf hukukunu ve vakıfların tarih içindeki gelişimlerini konu edinen çalışmaların kaynakçası için bk. Çınar ve Koyuncu Kaya 2015: 35-63; 147-154.
} 
Osmanlı Devleti'nin yönetim merkezi Divan-1 Hümayun'dan çıkan kararlar, ilk zamanlar Mühimme Defterlerine kaydedilmekteydi. Ancak reayaya tanınan Divan-1 Hümayun'a başvuru yapabilme hakkı, zamanla bürokrasinin ağırlaşmasına sebep olduğundan 1649 yılında yeni bir düzenlemeye gidildi. Bu yıldan itibaren doğrudan ya da kadı marifetiyle Divan-1 Hümayun'a taşınan davalara ait kararlar Şikâyet Defterleri adıyla müstakil defterlere kaydedilmeye başlandı (Genç vd. 2010: 21-22). 1742 senesinde Reisülküttab Mehmed Ragıb Efendi'nin girişimleriyle mahalli meselelerin çözümünü hızlandırmak için bu defterlerin eyalet esaslı olarak tutulmasına karar verildi. Böylelikle yeni bir seri olarak Eyalet Ahkâm defterleri ortaya çıktı (Emecen 2005: 125). Divan-1 Hümayun toplantılarının kaydedildiği bu üç defter serisinde, Osmanlı Devleti'nin idaresindeki bütün kazalarda yer alan vakıflarla ilgili hükümlere rastlamak mümkündür. Bu defter serilerinde yer alan vakıflarla ilgili hükümler incelenmeden vakıfların Osmanlı sosyal hayatındaki yerini tespit etmek bir yönüyle eksik kalacaktır.

$\mathrm{Bu}$ çalışma, Mühimme Defterleri'nden hareketle²; Osmanlı merkez yönetimine Bursa vakıflarıyla ilgili yansıyan şikâyetleri konu edinmektedir. Bu doğrultuda çalışma, Divan-1 Hümayun'a vakıflarla ilgili başvuruların; kimler tarafından, nasıl ve hangi konularda gerçekleştiğini ortaya koymayı ve böylelikle literatüre katkı yapmayı amaçlamaktadır. Çalışmanın mekânsal sınırını Osmanlı Devleti'nin kuruluş döneminin en önemli şehirleri arasında yer alan Bursa,

\footnotetext{
${ }^{2}$ Bursa vakıflarıyla ilgili Mühimme Defterlerinde yer alan hükümlerin her biri bizzat ilgili arşiv malzemesi elde edilerek incelenmiştir. Bunun yanında T. C. Cumhurbaşkanlığı Devlet Arşivleri Başkanlığı tarafından neşredilen Mühimme yayınlarından da istifade edilmiştir. Son yıllarda Mühimme defterlerinin transkript edilmesine yönelik yüksek lisans çalışmaları artış gösterse de paleografik zorluk nedeniyle defterlerde yer alan hükümlerin ya tam okunamaması ya da hatalı okunması gibi sebepler, bu çalışmalardan istifade etmemize imkân tanımamıştır.
} 
zamansal sınırını ise mühimme defterleri serisinin klasik dönemini oluşturan 1553-1649 yılları arası oluşturmaktadır.

\section{Vakıf-Şehir İlişkisi Bağlamında Bursa Vakıfları}

Bursa, Osmanlılar tarafından 1326 'da fethedilip beyliğin merkezi haline getirilince güvenlik meselesinin ardından öncelikli olarak şehrin imarına yönelik faaliyetlere önem verilmiştir. $\mathrm{Bu}$ faaliyetlerin başında gelen cami, mescit, medrese, zaviye, imaret ve sebil gibi hayratın inşası ile bu hayratta yürütülecek hizmetlerin sürekliliğini sağlamaya yönelik akar tahsisi, hep vakıflar aracılığıyla gerçekleştirilmiştir. $\mathrm{Bu}$ yönüyle vakıflar, meydana getirdiği dinî ve ticari merkezlerle şehrin imarına katkıda bulunmuş ve sosyal hayatın şekillenmesine öncülük etmişlerdir (İnalcık 1992: 446; Barkan ve Meriçli 1988: 121).

Bursa'da şehir hayatı ilk olarak Orhan Gazi tarafından sur dışında inşa edilen cami, medrese, imaret, hamam ve kervansaraydan müteşekkil külliyenin etrafında gelişmeye başlamıştır. Bunu müteakiben I. Murad, I. Bayezid, Çelebi Mehmed ve II. Murad dönemlerinde inşa edilen külliyeler ${ }^{3}$, şehrin doğu-batı ekseninde büyümesini sağlamış ve bu yapıların etrafında kurulan mahallelerde iskân artmaya başlamıştır ${ }^{4}$. Osmanlı fetih politikasının gereği olarak kendilerine temlik edilen arazileri hayır amaçlı kullanan kimselerin Bursa'da meydana getirdiği eserler de oldukça fazladır. Yıldırım Bayezid'in annesi Gülçiçek Hatun gibi bir valide sultan; Çandarlı Ali Paşa, Timurtaş Paşa ve Oruç Bey gibi devlet ricali; Molla Fenari ve Emir Sultan gibi âlimler ve daha birçoğu Bursa'da inşa ettikleri hayrat ile şehrin imarına katkıda bulunmuşlardır ${ }^{5}$. Böylelikle Bursa'da vakıflar

\footnotetext{
${ }^{3}$ Selatin imaretleri olarak bilinen bu külliyeler hakkında bk Hızlı 2001: 33-62.

${ }^{4}$ 1487, 1521 ve 1573 tarihlerinde Bursa Kazasındaki mahallelerin iskân durumu için bk. Barkan ve Meriçli 1988: 1-9.

${ }^{5}$ Zikri geçen isimlere ve daha fazlasına ait vakfiyeler için bk. Öcalan vd. 2013.
} 
aracılığıyla meydana getirilen hayrat ile şehrin Osmanlı kimliği kazanması sağlanmıştır (Başol 2003: 90-92; Ateş 2017: 156-157). Ayrica bu hayrata tahsis edilen akarlar sayesinde hayratın asırlara meydan okuması için gerekli olan tamirler gerçekleştirilmiş ve böylelikle şehrin estetik görünümü muhafaza edilmiştir. Vakıfların mütevelli, cabi, imam, müezzin, müderris, ferraş ve bevvab gibi Bursa halkına sağladığı iş istihdamları da şehir ekonomisine artı bir değer katmıştır. Bu anlamda Bursa'nın fethiyle birlikte sultan ve vezir vakıflarının şehrin siluetinde büyük bir değişiklik meydana getirdiği ve özellikle şehrin sosyal ve ekonomik hayatını canlandırdığını söylemek mümkündür.

Osmanlı Bursa'sının ilk dönemlerinde sultan, hanedan mensupları ve yüksek rütbeli devlet ricali tarafından kurulan vakıflar, şehir halkı tarafından kurulan diğer küçük vakıflarla birlikte düşünüldüğünde Bursa'da zengin bir vakıf kültürü oluşturulduğu karşımıza çıkmaktadır. Öyle ki XVII. yüzyılın ilk yarısında Bursa'da kurulan vakıf sayısı 617 iken yüzyılın sonunda bu sayı 811'e yükselmiştir (Başol 2008: 54-55). XVII. yüzyıl Bursa vakıflarının hizmet çeşitliliğine bakıldığında bir vakfın birden fazla alanda faaliyet gösterdiği anlaşılmaktadır. Bu sebeple vakıfların hizmet türleri sayısı 2103'e ulaşmaktadır. Samettin Başol (Başol 2008: 150-151) tarafından hazırlanan tablo bu hizmet alanlarını toplu biçimde göstermesi bakımından oldukça faydalıdır. 
Tablo 1: XVII. Yüzyılda Bursa Vakıflarının Hizmet Türleri

\begin{tabular}{|c|c|c|c|c|c|}
\hline $\begin{array}{l}\text { Hizmet } \\
\text { Birimleri }\end{array}$ & \multicolumn{2}{|r|}{ Hizmet Türleri } & Sayısı & Toplam & Yüzde \\
\hline \multirow{21}{*}{ 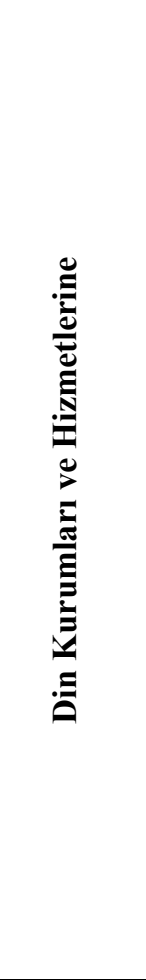 } & \multirow{12}{*}{  } & Cami imamina & 124 & \multirow[t]{12}{*}{530} & \multirow[t]{12}{*}{$\% 25,2$} \\
\hline & & Cami müezzinine & 62 & & \\
\hline & & Cami kayyımına & 47 & & \\
\hline & & Cami hatib/vaizine & 31 & & \\
\hline & & Cami muarrifine & 4 & & \\
\hline & & Cami kandilcisine & 1 & & \\
\hline & & Mescid imamına & 124 & & \\
\hline & & Mescid müezzinine & 56 & & \\
\hline & & Mescid mütevellisine & 1 & & \\
\hline & & Mescit kandilcisine & 1 & & \\
\hline & & Tekke şeyhine ve fukarasına & 77 & & \\
\hline & & Türbedara & 2 & & \\
\hline & \multirow{3}{*}{ 总莺 } & Cami masraflarına & 70 & \multirow[t]{3}{*}{149} & \multirow[t]{3}{*}{$\% 6,6$} \\
\hline & & Mescit masraflarına & 46 & & \\
\hline & & Tekke masraflarına & 33 & & \\
\hline & \multirow{5}{*}{  } & Cüz & 14 & \multirow[t]{5}{*}{604} & \multirow[t]{5}{*}{$\% 28,7$} \\
\hline & & Sure & 550 & & \\
\hline & & Aşır & 1 & & \\
\hline & & Mevlid & 36 & & \\
\hline & & Muhammediye & 3 & & \\
\hline & \multicolumn{3}{|c|}{ Ara Toplam } & 1283 & $\% 61,0$ \\
\hline \multirow{5}{*}{ 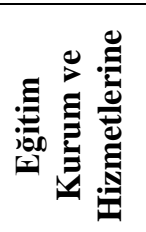 } & \multirow{5}{*}{ 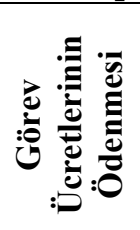 } & Muallime & 15 & \multirow[t]{5}{*}{29} & \multirow[t]{5}{*}{$\% 1,3$} \\
\hline & & Müderrise & 3 & & \\
\hline & & Ulemaya & 1 & & \\
\hline & & Dersiama & 4 & & \\
\hline & & Mekteb talebelerine & 6 & & \\
\hline
\end{tabular}

Uludağ Üniversitesi Fen-Edebiyat Fakültesi Sosyal Bilimler Dergisi Uludağ University Faculty of Arts and Sciences Journal of Social Sciences Cilt: 21 Sayl: 38 / Volume: 21 Issue: 38 


\begin{tabular}{|c|c|c|c|c|c|}
\hline & 国 & Mekteb masrafları & 3 & 3 & $\% 0,1$ \\
\hline & \multicolumn{3}{|l|}{ Ara Toplam } & 32 & $\% 1,5$ \\
\hline \multirow{6}{*}{  } & & Fakirlere & 302 & \multirow[t]{5}{*}{687} & \multirow[t]{5}{*}{$\% 32,6$} \\
\hline & & Mahalle avarızına & 148 & & \\
\hline & & $\begin{array}{lcc}\text { Yemek pişirilmesi } & \text { ve } \\
\text { dağıtımına (Taamiye) } & \\
\end{array}$ & 76 & & \\
\hline & & Haremeyn fukarasına & 160 & & \\
\hline & & Gelip geçen yolculara & 1 & & \\
\hline & \multicolumn{3}{|c|}{ Ara Toplam } & 687 & $\% 32,6$ \\
\hline \multirow{10}{*}{  } & \multirow{4}{*}{  } & Kaldırım & 2 & \multirow[t]{4}{*}{10} & \multirow[t]{4}{*}{$\% 0,4$} \\
\hline & & Köprü & 2 & & \\
\hline & & Han & 5 & & \\
\hline & & Ribat & 1 & & \\
\hline & \multirow{4}{*}{$\overline{\tilde{D}}$} & Sebil & 1 & \multirow[t]{4}{*}{24} & \multirow[t]{4}{*}{$\% 1,2$} \\
\hline & & Şadırvan & 2 & & \\
\hline & & Hamam & 2 & & \\
\hline & & $\begin{array}{l}\text { Çeşme ve suyolları tamir ve } \\
\text { bakımı }\end{array}$ & 19 & & \\
\hline &  & $\begin{array}{l}\text { Ev, Dükkân, bahçe vb. hayrat } \\
\text { ve akarın bakım ve onarımı }\end{array}$ & 66 & 66 & $\% 3,1$ \\
\hline & Ara Toplam & & & 100 & $\% 4,8$ \\
\hline Genel & & & & 2103 & $\% 100$ \\
\hline
\end{tabular}

XVII. yüzyıl Bursa vakıflarının hizmet alanlarında, din kurumları ve hizmetlerinin en büyük paya sahip olduğu anlaşılmaktadır. İmam, müezzin, hatip ve vaizlerin maaşlarının ödenmesi, ibadet mekânlarının aydınlatılması ve öldükten sonra vâkıfın ruhuna Kur'ân ve

Uludağ Üniversitesi Fen-Edebiyat Fakültesi Sosyal Bilimler Dergisi Uludağ University Faculty of Arts and Sciences Journal of Social Sciences Cilt: 21 Sayl: 38 / Volume: 21 Issue: 38 
mevlit okunması gibi din hizmetlerine ait oranın yüksek olması; din görevlileri maaşlarının vakıflar marifetiyle karşılanması teamülüne ve Müslümanlar tarafından önemsenen ölünün ardından sure ve dua okuma ritüeline bağlıdır. Din hizmetlerinden sonra en büyük orana sahip olan sosyal yardım hizmetlerinin, daha çok fakir ve düşkünlere yönelik hizmetler sunduğu görülmektedir. Bir mahallede veya esnaf loncalarında hastalık veya doğal afetler dolayısıyla geçim sıkıntısı yaşayanların iaşesine, fakir olarak vefat edenlerin cenaze masraflarına, sokaklardaki kaldırım ve suyolları gibi yerlerin tamirine sarf olunmak üzere kurulan avarız vakıflarının (Pakalın 1983: 114) Bursa'daki vakıflar içerisinde önemli bir yer tuttuğu tablodan anlaşılmaktadır ${ }^{6}$. Yine tablodan fakir halkın doyurulmasına yönelik taamiye vakıfları ile halkın su ihtiyacının giderilmesine yönelik su vakıflarının kurulduğu görülmektedir. Sıcak ve soğuk sularıyla meşhur olan Bursa'da kurulan su vakıfları halkın gerek içme gerekse temizlik suyu ihtiyacının karşılanmasına hizmet etmektedir ${ }^{7}$. Öyle görülüyor ki XVII. yüzyılda Bursa'da kurulan vakıflar; dinî hizmetlerden eğitim hizmetlerine ${ }^{8}$, sosyal hizmetlerden beledî hizmetlere kadar şehre geniş yelpazede hizmet imkânı sağlamışlardır.

\section{Divan-ı Hümayun'da Bursa Vakıfları}

Mühimme Defterlerinin klasik dönemini oluşturan 1553-1649 yılları arasında Bursa vakıflarıyla ilgili olarak 114 karar tespit edilmiştir. Bu kararlara konu olan vakıfların isimleri şöyledir:

\footnotetext{
${ }^{6}$ Bursa'daki avarız ve para vakıfları üzerinde yoğunlaşan bir çalışma için bk. Çiftçi 2004.

${ }^{7}$ Bursa su vakıfları için bk. Çiftçi 2002: 57-74; Karataş 2008: 379-417.

${ }^{8}$ 17. yüzyılda Bursa'daki vakıf eğitim kurumları için yapılan müstakil bir çalışma için bk. Başol ve Düzbakar 2009: 1-14.
} 
Tablo 2: Mühimme Defterlerinde Adı Geçen Bursa Vakıfları

\begin{tabular}{|l|c|}
\hline \multicolumn{2}{|c|}{ Vakıf İsmi } \\
\hline $\mathbf{1}$ & Yıldırım Bayezid \\
\hline $\mathbf{2}$ & Seyyid Muhammed el-Buhari \\
\hline $\mathbf{3}$ & Şehzade Sultan Mehmed Han \\
\hline $\mathbf{4}$ & Ulucami \\
\hline $\mathbf{5}$ & Gazi Hüdavendigar Murad Han \\
\hline $\mathbf{6}$ & II. Murad \\
\hline $\mathbf{7}$ & Kazzazoğlu \\
\hline $\mathbf{8}$ & Sultan Orhan \\
\hline $\mathbf{9}$ & Umur Bey \\
\hline $\mathbf{1 0}$ & Hacı Ali Oğlu \\
\hline $\mathbf{1 1}$ & Kasım Subaşı \\
\hline $\mathbf{1 2}$ & Timurtaş Paşa \\
\hline $\mathbf{1 3}$ & Fatma Sultan \\
\hline $\mathbf{1 4}$ & Ayn Hatun \\
\hline $\mathbf{1 5}$ & Şehzade Mustafa Validesi (Mah-1 Devran Sultan) \\
\hline $\mathbf{1 6}$ & Şahi Medresesi \\
\hline $\mathbf{1 7}$ & Mahmud Paşa \\
\hline $\mathbf{1 8}$ & Molla Yegân Medresesi \\
\hline $\mathbf{1 9}$ & Mollacık \\
\hline $\mathbf{2 0}$ & Şeyh Hüseyin Erzincanî \\
\hline $\mathbf{2 1}$ & Kadri Çelebi \\
\hline $\mathbf{2 2}$ & İvaz Paşa \\
\hline $\mathbf{2 3}$ & Asporça Hatun \\
\hline $\mathbf{2 4}$ & Rüstem Paşa \\
\hline $\mathbf{2 5}$ & Paşa Çelebi \\
\hline $\mathbf{2 6}$ & Hamza Bey \\
\hline & \\
\hline
\end{tabular}

Tablodaki veriler, Divan-1 Hümayun'da Bursa'daki vakıflardan daha çok sultan, hanım sultan, valide sultan ve paşa vakıflarıyla ilgili kararların alındığını göstermektedir. Bu duruma, ilgili vakıfların diğer vakıflara nazaran idari ve mali yönden daha büyük olması ve bununla doğru orantılı olarak daha büyük problemlerle karşılaşmaları neden olmuştur. $\mathrm{Bu}$ kararların alınma nedenleri ise birbirinden farklılık 
göstermektedir. Zira Divan-1 Hümayun'da idari, siyasi ve örfi meselelerle ilgili alınan kararlar re'sen, bunların dışındakiler ise bir talep veya şikâyet üzerine alınmaktaydı. Nitekim farklı din, dil, ırk, mezhep ve kültüre sahip Osmanlı tebaasının her biri, ister doğrudan ister yerel mahkemeden sonra Divan-1 Hümayun'a şikâyet başvurusu yapabilmekteydi (Uzunçarşı1ı 1988: 13). Buna göre; Bursa vakıflarına dair alınan 114 kararın on ikisinin re'sen, yirmi yedisinin talep ve kalan yetmiş beşinin şikâyet üzerine alındığı tespit edilmiştir.

Grafik 1: Divan-1 Hümayun'da Bursa Vakıflarılla İlgili Kararların Alınma Sebepleri



Re'sen alınan kararların büyük çoğunluğunu Haremeyn ve selatin vakıflarının teftiş edilmesi meselesi oluşturmaktadır 9 . Bu hükümler genellikle teftişin kolaylıkla yürütülmesine yönelik defterler

9 Bursa'daki Haremeyn ve selatin vakıflarının teftişiyle ilgili hükümler için bk. Yıldırım vd. 1998: C. I, 9; A. DVNS. MHM. d. 39, hüküm: 451, 454; A. DVNS. MHM. d. 41, hüküm: 266, 552, 869; A. DVNS. MHM. d. 46, hüküm: 207; A. DVNS. MHM. d. 49, hüküm: 505; A. DVNS. MHM. d. 51, hüküm: 151; A. DVNS. MHM. d. 62, hüküm: 182, 563). 
ile ilgili vazifelileri teftiş esnasında hazır etmesi için dönemin Bursa Kadısı'na ya da teftişte dikkat edilmesi gereken hususların bildirilmesine yönelik teftiş memurlarına hitaben yazılmıştır. İncelediğimiz dönemde bu vakıfların teftiş memurları Anadolu Kazaskerliği'nden emekli Muhyiddin ile Hazine-i Amire Defterdarlığı'ndan emekli Mustafa'dır.

Divan-1 Hümayun'a Bursa vakıflarıyla ilgili yapılan talep ve şikâyet konularının mahiyeti ise farklılık göstermektedir. Ancak bu hususun detaylarına geçmeden önce, talep ve şikâyet başvurularının nasıl gerçekleştirildiği meselesine açıklık getirmek yerinde olacaktır. Bununla ilgili olarak hükümlerde yer alan bazı ifadeler başvuruların çoğunlukla nasıl gerçekleştirildiğini ortaya koymaktadır. Buna göre; "gelüp" ifadesi başvurunun bizzat başvuru sahibi tarafından Dersaadet'e gelerek yapıldığını, "adam gönderüp" ifadesi ise başvurunun gerçek kişi adına bir başkasının vekâletiyle yapıldığını göstermektedir. "arz/mektub/rik'a/tezkire gönderüp" ifadeleri başvuru sahibinin dilekçe göndermek suretiyle Divan-1 Hümayun'a başvuruda bulunduğunu ortaya koymaktadır. Son olarak "i lam/mektub gönderüp" ifadeleri kadı, sancakbeyi ve darüssaade ağası gibi devlet ricalinin Divan-1 Hümayun'da görülmesini gerekli gördükleri meseleleri devlet merkezine bildirdikleri anlamına gelmektedir. 
Grafik 2: Divan-1 Hümayun’a Bursa Vakıflarıyla İlgili Yapılan Başvuru Türleri

\section{Başvuru Türleri}



Grafikten; sadece vekil aracılığıyla yapılan başvuru oranın düşük olduğu, diğer başvuru türlerinin toplam içindeki oranlarının ise birbirine yakın olduğu anlaşılmaktadır. Yerine adam gönderüp Divan-1 Hümayun'a başvuruda bulunanların bu yöntemi tercihlerinin sebepleri noktasında ilgili hükümler bazı ipuçları sunmaktadır. Buna göre; yol ücreti ile davanın görüşüleceği güne kadar geçen sürede iaşe ve ibate masrafını karşılayamama gibi maddi imkânsızlıklar, sahip olduğu makam itibariyle vakit harcamak istememe ve iş yoğunluğu sebebiyle başka personel gönderme gibi hususların bu duruma sebep olduğunu söylemek mümkündür. Nitekim babalarının ölümünden sonra tasarrufunda olan vakıf çiftliğin kendilerine geçmesi gerektiğini düşünen Bursalı iki yetim (A. DVNS. MHM. d. 41, hüküm: 345), maddi imkânsızlıklar sebebiyle Bursa'dan Dersaadet'e gitmeye güç yetiremeyip davanın kendileri için önemine binaen Dersaadet'e giden bir tanıdıklarına bu hususta Divan-1 Hümayun'a başvurmasını rica etmiş olması kuvvetle muhtemeldir. Dersaadet'te ikamet etmesine rağmen Hekim Çelebi Dergâhı Şeyhi Muhyiddin (A. DVNS. MHM. d. 41, 
hüküm: 661, 663), taşıdığı sufi kimlik sebebiyle devlet kapısında vakit harcamak yerine bir müridini göndererek davasını takip ettirmiş olabilir. Bursa'da Şehzade Mustafa Validesi Vakfı'nın mütevellisi (A. DVNS. MHM. d. 47, hüküm: 620) ise vakfi ihya etmek için bulunduğu girişimde iş yoğunluğundan dolayı Dersaadet'e gidemeyip bu işi vakıf görevlilerinden birine tevdi etmiş olabilir. Başvuru türleri arasında dilekçe yoluyla yapılan başvuruların en fazla orana karşılık gelmesinde, yine Dersaadet'e her zaman kolaylıkla gidilememesi (Mumcu 2017: 79) etkili olmuştur.

Bursa'dan Dersaadet'e bizzat gelüp talebini veya şikâyetini Divan-1 Hümayun'a bildirenlerin yaklaşı beşte bir orana tekabül ettiği grafikten anlaşılmaktadır. Kendi davalarını takip etmek isteyen bu başvuru sahiplerinin maddi durumları ile zamanlarının müsait olduğunu ya da önem verdikleri davaları sonuçlandırmak için birtakım sıkıntılara katlandıklarını söylemek mümkündür. Çoğunluğu kadı olmakla birlikte sancakbeyi ve darüssaade ağaları tarafından Divan-1 Hümayun'a yapılan başvurular da önemli bir orana tekabül etmektedir. Bu türden başvuruların artmasında, özellikle Bursa Kadısı'nın tek başına karar vermeyi uygun görmediği yerel davalar hakkında Divan-1 Hümayun'dan görüş talep etmesi etkili olmuştur. Sancakbeyi tarafından gönderilen mektuplar dolayısıyla çıkan hükümler ise daha çok Bursa'da vakıf reayasına yönelik baskı ve zulüm yapan kimselerin bundan men edilmesine yöneliktir. Darüssaade ağalarının Bursa'daki vakıflarla ilgili Divan-1 Hümayun'a yaptıkları başvurular, Bursa'da Haremeyn vakıflarının çokluğu ve bu vakıfların nazırlık görevinin 1588 senesi itibariyle darüssaade ağalarına tevdi edilmesiyle alakalıdır. Bu yönüyle darüssaade ağaları Bursa'daki Haremeyn vakıflarının hukuklarının korunması için gerekli adımları atarak Divan-1 Hümayun'a başvuruda bulunmuşlardır.

Bursa vakıflarıyla ilgili Divan-1 Hümayun'a yapılan başvuruların nasıl gerçekleştiğini ve hangi vakıflar hakkında kararlar 
çıktığını bu şekilde tespit ettikten sonra şimdi, bu kararların hangi konular üzerinde yoğunlaştığı ortaya koyulacaktır. Öyle ki bu konuyu Vakıf Görev ve Görevlileri ile Vakfin İhyasina Yönelik Tedbirler olmak üzere iki ana başlıkta incelemek mümkündür.

\subsection{Vakıf Görev ve Görevlileri}

\subsubsection{Tevcih ve Tahsislerde Yaşanan Mücadeleler}

Vakıf görevlerinin tevcih edilmesi veya vakıf gelirlerinden şahıslara tahsis yapılmasıyla ilgili Mühimmelere yansıyan kayıtlar, vakıfların Bursa'nın Osmanlı dönemi iktisadi hayatındaki önemini ortaya koyması bakımından dikkat çekicidir.

Vakıflarla ilgili yaşanan mücadelelerden biri vakıfların zevaidi ile ilgilidir. Bir vakfın aylık veya yıllık giderleri karşılandıktan sonra kalan gelir fazlası anlamına gelen zevaid, hizmet karşılığı olmaksızın herhangi bir sebeple şahıslara tahsis edilmekteydi (Pakalın 1983: C. 3, 656). Bursa'da zevaide sahip olan vakıflardan özellikle görevinden herhangi bir gerekçeyle ayrılmak zorunda kalanlara emekli maaş ${ }^{10}$ veya görevini başarıyla yerine getirenlerin kendilerine ya da aile fertlerine ikramiye ${ }^{11}$ kabilinden tahsiste bulunulduğu görülmektedir. Bundan başka, vakıflardan tahsis alanlar arasında ilim erbabına öncelik tanındığı ilgili hükümlerden anlaşılmaktadır. Ulucami imamı Seyyid Ali'nin ölümüyle oğlu Seyyid Mehmed'e Emir Sultan Evkafı zevaidinden yedi akça bağlanması talebinde, Seyyid Mehmed'in yetim kalmasından ziyade ilim ehlinden olduğuna vurgu yapılmıştır (A. DVNS. MHM. d. 25, hüküm: 2438). Yine aynı vakfın zevaidinden günlük iki akçaya sahip olan Hasan Şikarî'nin ölümüyle bu tahsise talip

${ }^{10}$ Bununla ilgili bazı hükümler için bk A. DVNS. MHM. d. 2, hüküm: 2052; A. DVNS. MHM. d. 25, hüküm: 1329; A. DVNS. MHM. d. 25, hüküm: 2277.

${ }^{11}$ Bununla ilgili bazı hükümler için bk. A. DVNS. MHM. d. 8, hüküm: 583; A. DVNS. MHM. d. 25, hüküm: 955; A. DVNS. MHM. d. 45, hüküm: 2426. 
olan Hacı Hayreddin'in de ilim erbabından olduğu üzerinde durulmuştur (A. DVNS. MHM. d. 45, hüküm: 2578).

Eskiden Şehzadeler Vakfı mütevellisi olan Seydi Ali'nin yeni bir tevliyet görevinin kendisine tevcih edilmesi için Divan-1 Hümayun'a bizzat başvuruda bulunması, vakıf gelirlerinden geçimini sağlayan kişiler için bu gelirlerin ne kadar önemli olduğunu ortaya koymaktadır. 10 Zilhicce 961/6 Kasım 1554 tarihli hükme göre, Seydi Ali'nin bu isteğine olumlu cevap veren Divan-1 Hümayun, Bursa'daki vakıflarda boş bir tevliyet kadrosu bulunmaması sebebiyle ileride boşalacak bir tevliyet görevinin kendisine verilmesini kararlaştırmıştır (A. DVNS. MHM. d. 1, hüküm: 895). Bu hükümden Seydi Ali'nin, Bursa'da herhangi bir vakfın tevliyet görevine talip olduğu anlaşılmaktayken, bazı hükümlerden ise özellikle ölüm sebebiyle boşalan görevlerin doğrudan halk tarafından takip edildiği anlaşılmaktadır. Bu hususta Sultan Murad İmareti'nin günlük on beş akçalık meşihat görevini yürüten Şeyh Mehmed'in ölümüyle bu göreve talip olan Muhsin'in Bursa kadısına yaptığı başvuru, kadı tarafından Divan-1 Hümayun'a taşınmıştır. Ancak çıkan kararda bu atama uygun görülmeyip vazife bedelinin hazineye kalması emredilmiştir (A. DVNS. MHM. d. 15, hüküm: 298). Yine Bursa'da Umur Bey Evkafı zevaidinden beş akça tahsise sahip Şah Çelebi oğlu Mehmed'in ölümüyle tahsisin boş kaldığını bildiren Kabil, bu tahsise talip olmuştur. Kendisini Koca Nişancı Bey'in kullarından ve artık hasta ve dermansız biri olarak tavsif eden Kabil, tahsisin tamamını elde edemese de üç akçalık kısmını elde etmeyi başarmıştır (A. DVNS. MHM. d. 15, hüküm: 1294).

Bursa'daki Sultan Mehmed Han İmareti şeyhliğini elde etmek isteyen Mevlana Resul ise bu hususta uzun süren bir mücadeleye girişmiştir. 987/1579 senesinde imaretin şeyhlik görevini yürüten Hüseyin'in içki içen günahkâr bir kimse olduğunu halkın şahitliğiyle Bursa mahkemesine bildiren ve vâkıfın şartı üzere şeyhlik vazifesinin ulemadan birine tevcih edilmesi gerektiğini savunan Mevlana Resul'ün 
bu husustaki mücadelesi kadı tarafından Divan-1 Hümayun'a taşınmıştır (A. DVNS. MHM. d. 37, hüküm: 1985). Ancak aradan yaklaşık iki yıl geçmesine rağmen bir sonuç elde edemeyen Mevlana Resul, bu defa Divan-1 Hümayun'a bizzat başvurarak iddialarını yenilemiş ve bunun üzerine Bursa kadısının Hüseyin ile Mevlana Resul'ü imtihan etmesi ve imtihan sonucuna göre her kim layık ise onu imaret şeyhi olarak ataması emredilmiştir (A. DVNS. MHM. d. 45, hüküm: 691).

Vakıf tahsis ve tevcihlerini elde etmek için verilen mücadelelerde birtakım hilelere de başvurulduğu görülmektedir. Bununla ilgili Seyyid Hasan, Sultan Murad Han Evkafı zevaidinden üç akçaya mutasarrıf Seyyid Baki'yi; Seyyid Mehmed ise Seyyid Mehmed Buhari Evkafı zevaidinden üç akçaya mutasarrıf Seyyid Mustafa'yı, Bursa naibinin mühür ve imzasını taklit ederek vefat etmiş gösterip bu tahsisleri uhdelerine geçirmişlerdir. Ancak yapılan tahkikat sonucunda naibin mühür ve imzalarının sahte olduğu anlaşılınca olayın failleri Seyyid Hasan, Seyyid Mehmed, arzları yazanlar ve mühürü kazanların her birinin yakalanarak Dersaadet'e gönderilmeleri Bursa kadisına emredilmiştir (A. DVNS. MHM. d. 16, hüküm: 346). Yine Sultan Murad Han Evkafi'yla ilgili başka bir hileli tahsis de 9 Şaban 987/1 Ekim 1579 senesindeki hükümle karara bağlanmıştır. Buna göre vakfın zevaidinden günlük on akça tahsise sahip olan Mehmed'in öldügünü iddia ederek görevi 982/1574 senesinde kendi uhdesine alan Mahmud'un bu tahsiste hile yaptığı Mehmed'in hayatta olduğu ortaya çıkınca anlaşılmıştır. Bunun üzerine Mahmud'un vakıftan beş sene boyunca aldığı parayı vakfa geri ödemesi ve tahsisin tekrar Mehmed'e yapılması emredilmiştir (A. DVNS. MHM. d. 41, hüküm: 73).

Sultan I. Süleyman zamanında ailesiyle birlikte Bursa’ya göç eden ve ikamet ettiği Bursa Hisarı içindeki Filboz Mahallesi civarında mescid, darülhadis ve mekteb inşa ederek bunlar için vakıf kuran Seyyid Hüseyin Erzincanî'nin (Maydaer 2007: 289) vakfında meydana gelen bir yolsuzluk iddiası ise bu gibi hileli davranışların vakıf yönetimi 
ya da personeli içerisinden de gerçekleşebileceği ihtimalini ortaya koymaktadır. Vâkıfın şartlarına göre evlada ait olması gereken vakıf zevaidine, mütevelli ve mürtezikaların el koydukları, bunu yaparken de asıl vakfiyeyi gizleyip sahte vakfiye hazırladıkları iddia edilmiştir. Divan-1 Hümayun, davayı Bursa kadısına havale ederek geçerli vakfiyeye bakılmasını ve eğer iddialar doğruysa mütevelli ve mürtezikaların bundan men edilmelerini emretmiştir (A. DVNS. MHM. d. 80, hüküm: 689).

Bursa'daki vakıf görevlerini elde etme hususunda halkın verdiği mücadelelerle ilgili bu örnekler, vakıfların şehirde önemli bir iş istihdamı sağladığını ortaya koymaktadır. Öyle ki bu görevleri elde etmek için halktan bazılarının meşru olmayan yollara tevessül etmesi, mücadelelerin ulaştığı boyutları gözler önüne sermektedir. Burada dikkat çeken husus; Bursa'da vakıf görevleri üzerinden bir mücadele alanı oluşmasına izin veren Devletin, hile ve sahtekârlık gibi meşru olmayan durumlar yaşandığında olaya derhal müdahale etmesidir. $\mathrm{Bu}$ yönüyle devlet otoritesinin vakıf görevleri paylaşımında görünür etkinliğinin, vakıfların işleyiş düzenine artı bir değer kattığı anlaşılmaktadir.

\subsubsection{Vakıf Görevlilerinin Kontrolü}

Vakıf görevlileri genel olarak idari ve hizmet sınıfı olmak üzere ikiye ayrılmaktadır. Nâzır, mütevelli, muhasip, cabi (tahsildar), kâtip gibi yönetim görevi yapanlar idari; müderris, hatip, imam, kütüphaneci, hekim gibi vakfin amacını gerçekleştirmek üzere vazife alan ihtisas sahibi kimseler de hizmet sınıfını oluşturmaktadır (Öztürk 1995: 169).

Bursa'daki vakıf görevlileriyle ilgili olarak vakıf malını zimmetine geçirme hususunda Divan-1 Hümayun'a daha çok şikâyet ulaştırıldığı görülmektedir. Konuyla ilgili olarak Vize'de bulunan Timurtaş Paşa Vakfı nazırı Cafer Halife, vakfa ait zaviyenin şeyhi Mehmed'in görevini yerine getirmediğinden şikâyetçi olmuştur. Vakfin 
akarlarından olan Bursa'daki Bademli Köyü gelirlerinin, vâkıf tarafindan kendisine şart edildiğini savunarak zaviyedeki fakirlere bir gün bile yemek çıkartmadığı iddia edilen zaviye şeyhi Mehmed'in zimmetinde bulunan 13.000 akçanın tahsil edilmesine karar verilmiştir (A. DVNS. MHM. d. 34, hüküm: 613). Aynı şekilde, Kazazoğlu Evkafi cabilerinin vakfa olmadık masraflar peyda ederek vakıf mallarını yedikleri (A. DVNS. MHM. d. 45, hüküm: 2393), Şahi Lala Medresesi Evkafı mütevelli kaymakamının küçük meblağlara görülebilecek tamir işlerini büyük meblağlara yaptırarak vakıf mallarını yemesi (A. DVNS. MHM. d. 51, hüküm: 17), Sultan Murad Han Evkafı mütevellisinin imareti kapatarak vakıf mahsulatını zimmetine geçirmesi (A. DVNS. MHM. d. 66, hüküm: 199), Yıldırım Bayezid Han evkafı mütevellisi Abdurrahman'ın vakıf mahsulünün bazısını ambara koyarak zayi etmesi ve bazısını da yemesi (A. DVNS. MHM. d. 78, hüküm: 1205) gibi vakıf görevlilerinin vakıf malını zimmetine geçirmeleri hakkındaki örnekleri artırmak mümkündür.

Vakıf görevlileriyle ilgili Divan-1 Hümayun'a yapılan bir diğer şikâyet konusu, görevin kötüye kullanılması ile ilgilidir. Gazi Hüdavendigar Evkafı reayasından üç çiftlik yere mutasarrıf olan iki kardeşin bu yerlerin kendilerine babalarından kaldığını kadı hüccetiyle ispatlamalarına rağmen vakfın mütevellisi çiftliklerden birini başkasına verdiği (A. DVNS. MHM. d. 41, hüküm: 345), Seyyid Emir el-Buhari Evkafi mütevellisinin imarette yemek hizmetlerini yürütmeyerek fakirleri aç biraktığı (A. DVNS. MHM. d. 46, hüküm: 795) ve Sultan Yıldırım Bayezid Evkafı mütevellisinin vakfın bazı köylerinden zamanı gelmeden öşür talep ederek halkı zimmi olan bu köylerden kendisine muhalefet eden zenginleri hapsettiği (A. DVNS. MHM. d. 78, hüküm: 1318) gibi şikâyetler bu hususa dair örneklerden bazılarıdır.

Vakıftan alacağı olan kişilerin bu alacaklarını vakıf görevlilerinden tahsil edememeleri yine Divan-1 Hümayun'da görülen davalar arasındadır. Bununla ilgili olarak Kasap Kara Yusuf, Yıldırım 
Bayezid Han İmareti Evkafi mütevellisi hakkında yaptığı şikâyette, imaret için verdiği et bedelinden 35.000 akça alacağı olduğunu, ancak mütevellinin ödeme yapmadığı bildirmiştir. Bunun üzerine kadıdan olayı tahkik etmesi ve doğruysa paranın mütevelliden tahsil edilerek Kara Yusuf'a verilmesi kararlaştırılmıştır (A. DVNS. MHM. d. 41, hüküm: 144). Sultan Mehmed Han türbedarı Hacı Ahmed'in başına gelen benzer bir olayda ise Hacı Ahmed, Dersaadet'e giderek şikâyette bulunmuş ve görevi karş1lığı günlük iki akça ve senede Bursa müddü ${ }^{12}$ ile altı müd buğday alması gerekirken mütevellinin buğdayı vermediğini bildirmiştir. Bu hususta da vakfiyedeki şart ne ise ona göre hareket edilmesi emredilmiştir (A. DVNS. MHM. d. 45, hüküm: 3583).

Son olarak Bursa'da Fatma Sultan Evkafi'nın görevlileriyle ilgili hükümle, yani bazı vakıf görevlilerinin vakfa hizmet etmeyerek haksız kazanç elde ettiği gerçeğini ortaya koyularak bu bahis tamamlanacaktır. Vakfın mütevellisi Hikmet, Dersaadet'e gelerek Divan-1 Hümayun'a yaptı̆̆ 1 başvuruda; Fatma Sultan'ın türbesinin harap olduğunu bildirerek bunun suçlusunun ise eczahanlar olduğunu iddia etmiştir. İddiasının dayanağı ise, vâkıfın şartında eczahanlar aynı zamanda türbedar olarak belirlenmiş olmasına rağmen eczahanların vâkıfın şartına aykırı olarak Dersaadet'te ikamet ettikleri ve 20-30 senedir türbenin sahipsiz bırakıldığıdır. Fatma Sultan Evkafı mütevellisinin bu iddialarının Bursa kadısı tarafından tahkik edilmesini emreden Divan-1 Hümayun, tahkik sonucuna göre karar verileceğini bildirmişstir (A. DVNS. MHM. d. 41, hüküm: 154).

Bursa'daki vakıf görevlilerinin kontrolüyle ilgili olarak vakıf malını zimmete geçirme, görevi kötüye kullanma, vakıftan alacaklıların haklarını vermeme ve görevini yapmama gibi hususlarda Divan-1 Hümayun'a yansıyan meselelerde çıkan kararlar, tıpkı vakıf görevlerin

12 Müd, Osmanlılar tarafindan da kullanılan eski bir hacim ölçüsü olup Bursa müdünün XVI. yüzyıldaki buğday için karşılığı 20 kile idi. (Kalle 2006: 458). 
paylaşımında olduğu gibi vakıflarını işleyiş düzenini korumaya yöneliktir. Vakıf görevinden elde ettiği nüfuzu kötüye kullanarak halka zulmeden kimselerin bu tür davranışlardan derhal men edilmelerine yönelik Divan-1 Hümayun kararları, Osmanlı Devleti'nin adalet anlayışının bir tezahürü olarak karşımıza çıkmaktadır.

\subsection{Vakfin İhyasına Yönelik Tedbirler}

\subsubsection{Vakıf Gelirlerinin Korunması}

Vakıflar tarafından yürütülen hizmetlerde sürekliliğin sağlanması bağ, bahçe, tarla ve değirmen gibi kırsal gelirler ile dükkân, han ve hamam kentsel işletmelerden elde edilen gelirlerde yaşanan istikrara bağlıdır. Burada, vakıfların gelirlerinde yaşanan istikrarsızlığın sebepleri önem arz etmektedir. Bu yönüyle Bursa'daki vakıflarda yaşanan gelir kayıplarıyla ilgili Divan-1 Hümayun'da görülen davalar, bu kayıların sebeplerini ortaya koyması bakımından oldukça önemli bilgiler sunmaktadır.

Vakıfların kırsal gelirlerini oluşturan bağ, bahçe ve tarlalardan mevsim şartlarına veya doğal afetlere bağlı olarak meydana gelen rekolte düşüklügünde duruma müdahale edilmesi pek mümkün değildir. Buna dair Yeşil İmareti Evkafı reayası, Divan-1 Hümayun'a yaptıkları başvuruda, bir sene fare ve üç sene de çekirge istilasından dolayı ekinlerinin zayi olduğunu ve mahsul elde edemediklerinden vakfa herhangi bir ödeme yapmaya durumları olmadığını bildirmişlerdir. Bu cihetten reayanın fare ve çekirge istilası hakkındaki iddialarının tahkik edilme görevi 26 Zilkade 983/26 Şubat 1576'da şehrin ileri gelenleri ve ziraat işlerinde uzman kişilere tevdi edilmiştir (A. DVNS. MHM. d. 27, hüküm: 704). Takip eden senelerdeki hükümlerden vakıf reayasının iddialarının doğru olup olmadığını tespit etmek mümkün olmadı. Ancak vakfin tarımsal gelirleri 1570 senesinde 247 bin akça civarındayken takip eden senelerde 213 bin akçaya kadar gerilemesi ve nihayet reayanın şikâyetinden bir yıl sonra yani 1577 senesinde 279 bin akçaya 
yükselmesi (Orbay 2007: 150-152) reayanın haklı olabileceğini göstermektedir.

29 Şaban 988/9 Ekim 1580 tarihli başka bir hükümden ise Bursa'da bu yılda yağmurların yetersiz olmasından dolayı kuraklık olduğu, kuraklığın ise Bursa'daki pirinç rekoltesinin geçmiş yıllara göre düşmesine sebep olduğu anlaşılmaktadır. Bursa'da bulunan sultan imaretlerinde fakirlere çıkarılacak yemekte, pirince olan ihtiyaç vazgeçilmez olduğundan imaret vakıflarının bu yılın pirinç ihtiyacını karşılamasında alternatif bir yola başvurulmuştur. $\mathrm{Bu}$ hususta imaretlerin ihtiyaç duyduğu pirinci, deniz yoluyla Mısır'dan tedarik ederek Mudanya İskelesi'ne getirmelerine izin verilmiştir (A. DVNS. MHM. d. 43, hüküm: 516).

Mevsim şartları veya doğal afetler sebebiyle vakıflarda yaşanan gelir kayıplarına yönelik alınan alternatif tedbirlerin aksine gelir kayıplarının insan kaynaklı olması durumunda daha kalıcı çözümler üretilmeye çalışıldığı bu konudaki birçok hükümden anlaşılmaktadır. Celali isyanlarının Bursa'daki uzantılarının yaşandığı yıllarda eşkıyaların vakıf köylere baskınlar düzenleyip reayaya zulmetmesi üzerine bunların derhal yakalanarak zulümlerine son verilmesi yönünde Bursa sancakbeyi ve kadılarını muhatap alan emirler sadır olmuştur ${ }^{13}$. Bununla ilgili bir olay II. Murad'ın vakıf köylerinden olan Manyas'ın Bölceağaç Köyü'nde yaşanmıştır. Manyas kadısı Dersaadet'e gönderdiği mektupta; Sultan Murad Han'ın Bursa'daki evkafindan olan Manyas'a bağlı Bölceağaç Köyü reayasının yerel mahkemeye gelerek eski Karesi Beyi Hamza'dan şikâyetçi olduklarını bildirmiştir. Şikâyetin

\footnotetext{
13 Vakıf reayasına zarar veren eşkıyalık hareketlerinin sonlandırılması için Bursa sancakbeyi ve kadısına gönderilen emirler için bk. A. DVNS. MHM. d. 30, hüküm: 19; A. DVNS. MHM. d. 46, hüküm: 103; A. DVNS. MHM. d. 55, hüküm: 254; A. DVNS. MHM. d. 72, hüküm: 845; A. DVNS. MHM. d. 73, hüküm: 555; A. DVNS. MHM. d. 76, hüküm: 390.
} 
ayrıntıları, vakıf reayasının vergilerini vakfa ödemelerine rağmen eski Karesi Beyi Hamza'nın 300-400 atlı ve 100 sekban eşkıyası ile köye konduğunu ve sekiz gündür kendilerine zulmettiği şeklindedir. Bu şikâyet üzerine Divan'da alınan 29 Safer 1018/3 Haziran 1609 tarihli kararda Bursa sancakbeyi ve kadısının duruma müdahale ederek köylüye yapılan zulmün derhal sonlandırılması emredilmiştir (A. DVNS. MHM. d. 78, hüküm: 2122). Vakfin 1608 ve 1609 senelerine ait aynî vergi tahsilatının yaklaşık üçte birini tahsil edememesinde (Orbay 2011: 311), yaşanan bu Celali hareketinin olumsuz etkileri olduğu anlaşılmaktadır.

Vakıf reayasına zulmedilmesiyle ilgili diğer bir olay, Bursa'da Seyyid Mehmed Buhari İmareti Vakfı reayası arasında gerçekleşmiştir. Vakfın mütevellisi Mustafa, vakıf reayasından olan Yörük ${ }^{14}$ taifesinden Hasan ve Hüseyin adlı kişilerin tüfekle cinayete varan suçlar işleyerek reayanın huzurunu kaçırdığından şikâyet etmiştir. Maktulün varislerinin sulh yoluna gitmesiyle faillerin serbest birakılmasının ise vakıf cabisinin işini yapmasına engel olduğunu bildiren mütevelli, gerçekleştirdiği bu şikâyetle faillerin kürek cezasına çarptırılmasını sağlayarak (Nezihi Aykut vd. 1993: 704-705) vakfın gelirlerini koruma altına almayı başarmıştır.

Vakıflara ait dükkân, han ve hamam gibi işletmelerdeki gelir kayıplarının nedenlerinin de çeşitli olduğu ilgili hükümlerden anlaşılmaktadır. Buna göre; Bursa'da Kasım Subaşı Evkafı mütevellisinin vakfa ait tabbah dükkânlarının yanında yeni açılan bazı dükkânların vakfı zarara uğrattığına dair şikâyeti, vakıf işletmelerinin rekabet ortamına sokulmak istenmediğini göstermektedir (A. DVNS. MHM. d. 23, hüküm: 296). Divan-1 Hümayun'un yeni açılan dükkânları

\footnotetext{
${ }^{14}$ Merkezi Bursa olan Hudâvendigâr Sancağı'nda yaşayan Yörük taifesinin büyük bir kısmı vakıf reayası olup bu hususta yapılan müstakil bir çalışma için bk. Alkan Günay 2017: 317-338.
} 
kapatma kararı bunu doğrulmakla birlikte, bu karar her ne kadar Bursa'daki bir vakfın gelir kaybına uğramasına engel olmuşsa da aynı zamanda şehir ekonomisine katkı sağlayabilecek gelişmelerin de önüne geçmiştir, denilebilir ${ }^{15}$. Vakıf dükkânlarının gelirlerinde kayıp yaşayan diğer bir vakıf ise Mahmud Paşa Vakfı'dır. İdam cezasına çarptırılan suçluların infazlarının son zamanlarda Mahmud Paşa Vakfi'na ait Bursa'daki han ve dükkânların önünde gerçekleştirildiğinin ve bu olayın vakfı zarara uğrattığının bildirilmesi üzerine Bursa kadısına infazların önceden nerede yapılıyorsa yine orada yapılmasına dair emir gönderilmiştir (A. DVNS. MHM. d. 53, hüküm: 127).

Vakıf gelirlerinin korunmasına yönelik tedbirlerden bir diğeri vakıf görevinden ayrılanların zimmetinde kalan vakıf paralarının tahsilidir. Sultan Mehmed İmareti Evkafı akarlarından olan Darıca Köyü'nü, vakfın mütevellisinden üç yıllık 94.000 akçaya iltizam eden Yafi adlı zimmi, bir önceki mültezim Abraham'ın borcunun da kendisine tahvil edildiğini bildirmiştir. Bunun üzerine Abraham'ın iltizam döneminin muhasebesini tekrar görülmesi ve Yafi'nin iddiası doğruysa bu borcun kendisinden silinerek Abraham'dan tahsil edilmesi emredilmiştir (A. DVNS. MHM. d. 41, hüküm: 836). Bu hadisenin bir benzeri Yeşil İmareti Evkafı mütevellileri arasında yaşanmıştır. Vakfın mütevellisi Hasan'ın görevinden azledilmesi üzerine zimmetinde bulunan vakıf malını tamamen vakfa geri ödediğini gösteren temessük ve hücceti yeni mütevelli Mustafa'dan almasına rağmen, Mustafa bunu inkâr ederek parayı yeniden talep etmiştir. Divan-1 Hümayun Mustafa'nın Dersaadet'e getirtilerek davanın Kazasker divanında görülmesini emretmiştir (A. DVNS. MHM. d. 85, hüküm: 49).

\footnotetext{
${ }^{15}$ Murat Tuğluca, XVII. yüzyıl Şikâyet Defterlerine göre yaptığı çalışmasında bu gibi durumlarda vakıfların şehir ekonomisine zarar verdiği hususuna daha önceden dikkat çekmiştir (Tuğluca 2016: 236).
} 


\subsubsection{Tamir ve Genişletme Faaliyetleri}

Vakfin ihyasına yönelik tedbirler arasında zamanla harap hale gelen hayrat ve akarların tamir edilmesi yer almaktadır. Vakıf bir hayratın harap olması buralarda yürütülecek hizmetlerin aksamasına, vakıf akarlarının harap olması ise vakıf gelirlerinde yaşanacak azalmaya bağlı olarak vakfın işleyişinin bozulmasına sebep olmaktadır.

Bursa kadısı, Yıldırım Bayezid Evkafı mütevellisi Ömer'in imaret işlerini düzgün bir şekilde yürüttügünü, ancak vakfın dükkânları, imareti, tabhanesi ve suyollarının kemerleri zamanla harap olmasına rağmen hiçbir önlem almadığını Dersaadet'e bildirmiştir. Divan-1 Hümayun, mütevellinin kemerleri derhal vakıf malından tamir ettirmesini ve bunu yaparken de vakıf mürtezikalarının hakkını yememesini karara bağlamıştır (A. DVNS. MHM. d. 76, hüküm: 137, 344). Ancak aradan çeyrek asra yakın bir zaman geçmesine rağmen tamir faaliyetinin gerektiği gibi yapılmadığ 1 ve bu hususa dair tedbirlerin artırıldığ 21 Şaban 1040/25 Mart 1631 tarihli hükümden anlaşılmaktadır. Buna göre vakfın tamire ihtiyaç duyulan mekânlarının tamir edilmediği ve hatta bu sebepten ötürü imaretin bir müddet kapatılarak hizmet vermediği Bursa Kadısı tarafından ikinci kez Dersaadet'e bildirilince bu defa vakfin nazırına vakıf zevaidinin sadece tamir işlerine sarf edilmesi emredilmiştir (A. DVNS. MHM. d. 85, hüküm: 217).

Bir başka tamir meselesi ise İvaz Paşa Vakfi'yla ilgilidir. Sultan Mehmed Han Evkafi'ndan olan İvaz Paşa Vakfı'nın han, türbe ve Bursa'daki camii kubbesinin kurşunları ile bazı dükkânlarının yanan yerlerinin tamir masrafi 18.330 akça olarak tespit edilmiş ve bu işin vakfin mütevellisi tarafından derhal gerçekleştirilmesi emredilmiştir (A. DVNS. MHM. d. 81, hüküm: 388). Yine Bursa'da Paşa Çelebi Vakfi'na ait medrese ve akarlarının tamire muhtaç olan yerleri için uzmanlar tarafindan muhammen bir bedel belirlenmiş ve tamirin mütevelli 
marifetiyle gerçekleştirilmesi emredilmiştir (A. DVNS. MHM. d. 82, hüküm: 353).

Tamir faaliyetlerinin yanı sıra görülen lüzuma binaen vakıf bir hayratın yahut gelirleri artırmak için akaratın genişletilmek istenildiği görülmektedir. Bu hususla ilgili olarak Seyyid Mehmed Buhari Türbesi'nde cüz okunan mahallin gayet dar olması buranın genişletilme talebini doğurmuştur (A. DVNS. MHM. d. 41, hüküm: 737). Şehzade Mustafa Validesi Evkafı mütevellisi ise vakfa bazı odaların inşa edilmesinin gerekli olduğunu, ancak inşaat için gerekli olan taşların tedarikinde sıkıntı olduğundan bu hususta taş kestirmeye izin istemiştir (A. DVNS. MHM. d. 47, hüküm: 620). Y1ldırım Bayezid'in Ulucamii Evkafı'nın gelirlerini artırmak maksadıyla Divan-1 Hümayun'a yapılan talebin, Bursa ayanı tarafından gerçekleştirilmesi dikkat çekicidir. Vakfın gelirlerindeki yetersizlik, cami mürtezikalarının vazifelerinin ödenememesine ve ayrıca caminin harap olan kısımlarının tamir edilememesine sebep olduğundan Bursa mukataatından İkizceler'in yılda 15.000 akçası veya Yeni Tahtakale'deki odaların Ulucami Evkafı'na ilhak edilmesi talep edilmiştir. Ancak Divan-1 Hümayun, bu talebi reddederek tamir işlerinin vakfın parasından yapılmasına karar vermiştir (A. DVNS. MHM. d. 48, hüküm: 174).

\section{Sonuç}

Bursa vakıflarının işleyişi, mali tarihi ve şehir hayatındaki önemi gibi konuları kadı sicillerinden hareketle ele alan çalışmaların aksine bu çalışmanın ana kaynağını Divan-1 Hümayun'da alınan kararların tutulduğu Mühimme Defterleri oluşturmaktadır. Bu yönüyle Mühimme Defterleri'ni Bursa vakıfları özelinde kullanan müstakil bir çalışmanın bulunmaması bu çalışmayı özgün kılmaktadır. Ancak çalışmanın sınırları yaklaşık bir asır gibi uzun bir dönemi kapsadığından, elde edilen bilgilerin kadı sicillerindeki hükümlerle mukayese edilememesi, çalışmayı bir yönüyle eksik kılmaktadır. Yine 
de bu çalışmada Mühimme Defterleri'nden elde edilen bilgiler, kadı sicillerinin ana kaynak olarak kullanıldığı literatürdeki diğer çalışmalarda yer alan bilgilerle karşılaştırılmaya özen gösterilmiştir. Şüphesiz Bursa vakıflarını doğrudan bu iki arşiv malzemesinin mukayesesiyle ele alan hacimli bir çalışma, konu hakkında daha aydınlatıcı bilgilerin ortaya koyulmasını sağlayacaktır.

Mühimme Defterleri'nde, Bursa vakıflarını konu edinen 114 kararın büyük bir kısmını sultan, hanım sultan, valide sultan ve paşa vakıfları oluşturmakla birlikte kararlar arasında reaya vakıflarının da bulunduğu tespit edilmiştir. Vakıflarla ilgili bu kararlar, re'sen alındığ 1 gibi bir talep veya şikâyet başvurusu üzerine de alınmıştır. Talep ve şikâyet başvuruları, başvuru sahibinin Divan-1 Hümayun'a bizzat gelmesiyle ya da vekil veya dilekçe göndermesiyle gerçekleşmiştir. Bunun yanında kadı, sancakbeyi ve darüssaade ağasının da Bursa vakıflarıyla ilgili meseleleri Divan'a taşıdıkları tespit edilmiştir.

Bursa vakıflarıyla ilgili Divan-1 Hümayun'da görüşülen meseleler çeşitlilik göstermektedir. Ancak bu meseleler vakıfların görev ve görevlileri ile vakfın ihyasına yönelik tedbirler konuları üzerinde yoğunlaşmaktadır.

Bursa vakıfları zevaidinden halkın oldukça istifade ettiği ilgili örneklerden anlaşılırken vakıf görevleriyle ilgili verilen mücadelelerde hileye dahi başvurulması, vakıfların Bursa halkına iaşe temininde önemli bir işlevi yerini getirdiğini göstermektedir. Vakıf görevlerini uhdesinde bulunduranlar hakkında; vakıf malını zimmete geçirme, görevi kötüye kullanma, vakıf düzenini bozma ve işini yapmama gibi şikâyetlerde ise Divan-1 Hümayun, aldığ k kararlarla vakıf işleyişinin bozulmasına engel olmuştur. Vakfin tarımsal gelirlerinden iklim ve doğal afetler sebebiyle yaşanan azalmalarda gerektiğinde alternatif çözümler üretildiği, insan unsuruna bağlı yaşanan azalmalarda ise eşkıyanın cezalandırılması, vakıf işletmelerine rakip diğer işletmelerin 
kapatılması, vakıfların eski görevlilerinde kalan paraların tahsil edilmesi gibi net çözümler üretildiği ortaya koyulmuştur. Vakıf hayrat ve akarlarından harap olanlarının tamiri meselesi, mütevellinin işini yapmaması veya tamir masrafının çok olması gibi sebeplerle zora girdiğinde mesele yine Divan-1 Hümayun'a taşınmıştır. Gerekli tamirlerin yapılmasıyla ilgili emirler, vakıfların hizmetlerini devam ettirmesine imkân sağladığı gibi harap binaların şehrin siluetine vereceği zararın da önüne geçilmiştir.

Son olarak Divan-1 Hümayun'da Bursa vakıflarıyla ilgili görülen davaların çoğunlukla Bursa kadısına havale edildiği tespit edilmiştir. Bursa kadısının tahkikine göre meselenin aydınlatılması ve ona göre hareket edilmesine dair bu emirler, aslında meselelerin çözümünde yerel mahkemenin önemine işaret etmektedir. Şikâyet sahibinin iddiasını temellendirecek delilleri ortaya koyamaması ve vakıflarla ilgili vakfiye, hüccet, temessük gibi kayıtların kadı sicillerinde mahfuz olması davaların Bursa kadısına havale edilmesine sebep olmuştur.

\section{Kaynaklar}

\section{Arşiv Kaynakları}

Başkanlık Osmanlı Arşivi Mühimme Defterleri (A. DVNS. MHM. d.) Defter No: 1, 2, 7, 8, 15, 16, 23, 25, 27, 30, 34, 37, 39, 41, 43, 45, 46, $47,48,49,51,53,55,62,66,72,73,76,78,80,81,82,85$.

\section{Tetkik Eserler}

Alkan Günay, Nilüfer (2017). "18. Yüzyıl Osmanlı Taşra Yönetim Düzeni Açısından Hudâvendigâr Sancağı'nda Yaşayan Vakıf Reayası Yörükler". Uludağ Üniversitesi Fen-Edebiyat Fakültesi Sosyal Bilimler Dergisi, C. 18, S. 33, s. 317-338.

Ateş, Nilüfer (2017). "Osmanlı'da Vakıf-Külliye-Şehir İlişkisi”. Uludağ Üniversitesi İlahiyat Fakültesi Dergisi, C. 26, S. 2, s. 151-164. 
Aykut, Nezihi vd. (1993). 3 Numaralı Mühimme Defteri 966-968/15581560. Ankara: Devlet Arşivleri Genel Müdürlügü Yayınları.

Barkan, Ömer Lütfi ve Enver Meriçli (1988). Hüdavendigâr Livası Tahrir Defterleri I. Ankara: Türk Tarih Kurumu Basımevi.

Başol, Samettin (2003). "Bursa Şehrinin Gelişmesinde XV. Yüzyıl Bursa Vakıflarının Rolü”. Bursa Defteri, Bursa: Bursa Kültür ve Sanat Yayınlar1, s. 82-112.

Başol, Samettin (2008). Kentleşme, Ekonomi ve Sosyal Hayat Yönleriyle 17. Yüzyıl Bursa Vakıfları. Doktora Tezi. Gazi Üniversitesi, Ankara.

Başol, Samettin ve Ömer Düzbakar (2009). "17. Yüzyılda Bursa'da Eğitim-Öğretim Hizmetlerine Yönelik Vakıflar”. Uludă̆ Üniversitesi Eğitim Fakültesi Dergisi, C. 22, S. 1, s. 1-14.

Çınar, Hüseyin ve Miyase Koyuncu Kaya (2015). Vakıflar Kaynakçası, Ankara: Vakıflar Genel Müdürlügü Yayınları.

Çiftçi, Cafer (2002). "Osmanlı Dönemi Bursa Su Yollarının Bakımı ve Onarımında Vakıfların Rolü”. Uludă Üniversitesi Fen-Edebiyat Fakültesi Sosyal Bilimler Dergisi, S. 3, s. 57-74.

Çiftçi, Cafer (2004). Bursa'da Vakıfların Sosyo-Ekonomik Işslevleri. Bursa: Gaye Kitabevi.

Emecen, Feridun (2005). "Osmanlı Divanının Ana Defter Serileri: Ahkâm-1 Mîrî, Ahkâm-1 Kuyûd-1 Mühimme, Ahkâm-1 Şikâyet”. Türkiye Araştırmaları Literatür Dergisi, C. 3, S. 5, s. 107-139.

Genç, Yusuf İhsan vd. (2010). Başbakanlık Osmanlı Arşivi Rehberi. Ankara: Devlet Arşivleri Genel Müdürlügüü.

Hızlı, Mefail (2001). "Bursa'da Selâtîn İmaretleri”. Uludağ Üniversitesi İlahiyat Fakültesi Dergisi, C. 10, S. 1, s. 33-62. 
İnalcık, Halil (1992). "Bursa". Diyanet İşleri Ansiklopedisi (DİA), İstanbul, C. 6, s. 445-449.

Kalle, Cengiz (2006). "Müd". Diyanet İslâm Ansiklopedisi (DİA), İstanbul, C. 31, s. 457-459.

Karataş, Ali İhsan (2008). "Bursa Suları ve Su Vakıfları". Uludă̆ Üniversitesi İlâhiyat Fakültesi Dergisi, C. 17, S. 2, s. 379-417.

Maydaer, Saadet (2007). "Seyyid Hüseyin Erzincanî Vakfi”. Uludă̆ Üniversitesi İlâhiyat Fakültesi Dergisi, C. 16, S. 2, s. 287-308.

Mumcu, Ahmet (2017). Divan-ı Hümayun. Ankara: Phoenix Yayınları.

Orbay, Kayhan (2007). "16. ve 17. Yüzyllarda Bursa Ekonomisi: Sultan Çelebi Mehmed Yeşil İmaret'inin Mali Tarihi (1553-1650)". Ankara Üniversitesi Osmanlı Tarihi Araştırma ve Uygulama Merkezi (OTAM) Dergisi, S. 22, s. 125-158.

Orbay, Kayhan (2011). "Bursa'da Sultan II. Murad Vakfi'nın Mali Tarihi (1608-1641)". İstanbul Üniversitesi İktisat Mecmuası, C. 23, S. 1-2, s. 293-322.

Orbay, Kayhan (2015). "Vakıfların Bazı Arşiv Kaynakları". Vakıflar Dergisi, S. 29, s. 27-42.

Öcalan, Hasan Basri vd. (2013). Bursa Vakfiyeleri I. Bursa: Bursa Kültür A.Ş.

Öztürk, Nazif (1995). Türk Yenileşme Tarihi Çerçevesinde Vakıf Müessesesi. Ankara: Diyanet Vakfi Yayınları.

Pakalın, Mehmet Zeki (1983). Osmanl Tarih Deyimleri ve Terimleri Sözlü̆̆̈̈. C. 3, İstanbul: Milli Eğitim Basımevi.

Tuğluca, Murat (2016). Osmanlı Devlet-Toplum Illişkisinde Şikâyet Mekanizması ve Işsleyiş Biçimi. Ankara: Türk Tarih Kurumu Yayınları.

Uludağ Üniversitesi Fen-Edebiyat Fakültesi Sosyal Bilimler Dergisi Uludağ University Faculty of Arts and Sciences Journal of Social Sciences Cilt: 21 Sayı: 38 / Volume: 21 Issue: 38 
Uzunçarş1lı, İsmail Hakk1 (1988). Osmanl Devleti'nin Merkez ve Bahriye Teşkilatı. Ankara: Türk Tarih Kurumu Basımevi.

Yıldırım, Hacı Osman vd. (1998). 7 Numaralı Mühimme Defteri 975976/1567-1569. Ankara: Devlet Arşivleri Genel Müdürlüğü Yayınları. 


\section{EKLER}



Ek I: Vakıf Görevlerinin Elde Edilmesinde Hile Yapıldığına Dair (A. DVNS. MHM. d. 16, hüküm: 346) 




Ek II: Vakıf dükkânların yanında açılan dükkânların kapatılması (A. DVNS. MHM. d. 23, hüküm: 296)



Ek III: Yeşil İmareti Evkafi reayasının fare ve çekirge istilasından şikâyetleri (A. DVNS. MHM. d. 27, hüküm: 704)

Uludağ Üniversitesi Fen-Edebiyat Fakültesi Sosyal Bilimler Dergisi Uludağ University Faculty of Arts and Sciences Journal of Social Sciences Cilt: 21 Sayl: 38 / Volume: 21 Issue: 38 




Ek IV: Yıldırım Bayezid Han Evkafı eski mütevellisinin vakfın malını zayi ettiğine dair (A. DVNS. MHM. d. 78, hüküm: 1205). 


\section{EXTENDED ABSTRACT}

There are many studies in the literature about waqfs that have an important place in Islamic civilization. When the sources of the researches about the waqfs of the Ottoman period are examined, it is seen that waqfiyyas and Ottoman court records (şer'iye sicils) were mostly used. Another archive source containing important information about waqfs is Mühimme registers. However, it has been found that this resource is almost never used by researchers. In this respect, this study is based on the decisions of the Imperial Council. The spatial boundary of the study is Bursa and the temporal boundary consists of the years 1553-1649, which constitute the classical period of the Mühimme registers.

In this study, firstly, the decisions regarding the Bursa waqfs in the Mühimme registers between 1553 and 1649 were determined. Afterwards, these decisions were classified according to their contents and thus the decisions taken regarding Bursa foundations were examined subject-centered. The information obtained from the decisions were compared with the studies in the literature about Bursa waqfs. Finally, the contribution of the decisions to Bursa waqfs was evaluated.

In this period, 114 decisions regarding Bursa waqfs were determined. These decisions are mostly related to sultan, lady sultan, valide sultan and pasha waqfs. This was caused by the fact that the related foundations were larger in administrative and financial terms than the other foundations and faced more problems in proportion to this. $90 \%$ of the 114 decisions were taken on the requests and complaints from Bursa. These requests and complaints have been made by the applicant himself, as well as by proxy or petition. Among these applications, it was determined that the applications made with the petition took the first place. This was due to the fact that complainants were not able to afford the travel and accommodation costs, as well as the lack of time to spend.

The decisions taken in relation to Bursa waqfs in Imperial Council; focuses on the duties of waqfs, incomes of waqfs, and repair activities for waqfs. Again, a number of individual issues regarding waqfs have been the subject of decisions.

In the decisions regarding the duties of the waqfs, it was determined that there were movements up to fraud in the struggles of the people of Bursa for these tasks. This finding reveals the importance of foundation duties for the people of Bursa. Decisions on embezzlement and abuse of office have made significant contributions to waqfs in terms of observing the waqf law. 
The information obtained from the Imperial Council decisions regarding the incomes of the waqf, especially the reasons of the decrease in agricultural incomes, helped to complete the missing information in the related literature. In addition, it has been determined that alternative solutions to income reductions caused by climate and natural disasters are produced. In the income decreases related to the human element, net solutions such as punishing the bandit, closing other competing enterprises and collecting the money left by the former officials of the waqfs were produced.

The decisions of the Imperial Council for the repair of waqfs prevented the destruction of the properties of the waqfs over time.

Finally, in the decisions taken in the Imperial Council about the Bursa waqfs, it was determined that the case was mostly directed to the Bursa judge. The fact that the person who filed a complaint with the Imperial Council could not put forward the evidence to base his claim and that the records of the waqfs were kept in şer'iye sicils led to the referral of these cases to the Bursa judge. 